\title{
Cellular Physiology

\section{BDNF Acutely Modulates Synaptic Transmission and Calcium Signalling in Developing Cortical Neurons}

\author{
Jun He, Hui Gong, Qingming Luo
}

The Key Laboratory of Biomedical Photonics of Ministry of Education, Huazhong University of Science and Technology, Wuhan

\section{Key Words}

BDNF • Calcium - Cultured cortical neurons - Synaptic plasticity $\bullet$ Voltage sensitive $\mathrm{Ca}^{2+}$ channels

\begin{abstract}
Brain-derived neurotrophic factor (BDNF), like other neurotrophins, has long-term effects on neuronal survival and differentiation; furthermore, BDNF has been reported to exert an acute potentiation of synaptic activity and are critically involved in long-term potentiation(LTP). We found that BDNF rapidly induced potentiation of synaptic activity and an increase in the intracellular $\mathrm{Ca}^{2+}$ concentration in cultured cortical neurons. Within minutes of BDNF application to cultured cortical neurons, spontaneous firing rate was dramatically increased as was the frequency and amplitude of excitatory spontaneous postsynaptic currents (EPSCs). Fura-2 recordings showed that BDNF acutely elicited an increase in intracellular calcium concentration $\left(\left[\mathrm{Ca}^{2+}\right]_{j}\right)$. This effect was partially dependent on extracellular $\mathrm{Ca}^{2+}$. In calcium-free perfusion medium a substantial calcium signal remained which disappeared after loading of cortical neurons with $5 \mu \mathrm{M} U-73122$. BDNF-induce $\mathrm{Ca}^{2+}$ transients were completely blocked by K252a and partially blocked by $\mathrm{Cd}^{2+}$. The results demonstrate that BDNF can enhance synaptic transmission and induce directly a rise in $\left[\mathrm{Ca}^{2+}\right]_{i}$ that require two routes: the release of $\mathrm{Ca}^{2+}$ from
\end{abstract}

\section{KARGER}

Fax +41613061234

E-Mail karger@karger.ch

www.karger.com
(C) 2005 S. Karger AG, Basel

1015-8987/05/0163-0069\$22.00/0

Accessible online at:

www.karger.com/journals/net intracellular calcium stores and influx of extracellular $\mathrm{Ca}^{2+}$ mainly through voltage-dependent $\mathrm{Ca}^{2+}$ channels in cultured cortical neurons.

Copyright (C) 2005 S. Karger AG, Basel

\section{Introduction}

Neurotrophins are a family of neurotrophic proteins that includes nerve growth factor (NGF), brain-derived neurotrophic factor (BDNF), neurotrophin-3 and neurotrophin-4/5 [1]. The neurotrophins mediate their actions by two types of receptors; that is, Trk receptor tyrosine kinases and the pan-neurotrophin receptor p75NTR. Each type of Trk is activated by one or several neurotrophins: TrkA by NGF, TrkB by BDNF or neurotrophin- $4 / 5$, and $\mathrm{TrkC}$ by neurotrophin-3. This specific binding leads to the receptor dimerization, activation, and recruitment of various adapter proteins to activate a wide range of signaling pathways. The role of neurotrophins as regulatory factors that mediate differentiation and survival of neurons in the peripheral and central nervous system is well established [2, 3]. Besides having longterm trophic functions, neurotrophins play pivotal roles in acute and long-term changes in synaptic plasticity $[4,5]$. 
In particular, BDNF acutely modulates the efficacy of basal synaptic transmission at developing neuromuscular junctions in cell cultures [6] and at central excitatory synapses in hippocampal and cortical cultures [7-9], acute slices [10, 11], and in vivo [12]. However, different systems show diverse responsiveness to BDNF and some discrepancies have yet to be clarified. In addition, brainderived neurotrophic factor (BDNF) plays an important role in activity-induced long-term potentiation (LTP) in the hippocampus, and might be necessary for the conversion of early-phase LTP to late-phase, protein synthesis-dependent, LTP [13].

In the present study we have investigated the effects of BDNF on synaptic transmission and calcium signaling in culture cortical neurons. We find that BDNF rapidly enhanced the strength of synaptic connections in cortical neurons. Both the amplitude and the frequency of excitatory postsynaptic currents (EPSCs) were increased within 3-5 min of BDNF application. Our data also show that BDNF acutely elicited an increase in intracellular calcium concentration $\left(\left[\mathrm{Ca}^{2+}\right]_{\mathrm{i}}\right)$, which is dependent on both the influx of extracellular calcium and calcium mobilization from intracellular calcium stores.

\section{Materials and Methods}

\section{Cell culture}

Primary cultures of cortical neurons were prepared from embryonic rats (E18) by a modification of the method previously described [14]. In brief, cortical tissues from $18 \mathrm{~d}$ fetal rats were dissected and treated with $0.25 \%$ trypsin and $0.25 \mathrm{mg} / \mathrm{ml}$ DNase (Sigma, St. Louis, MO) in $\mathrm{Ca}^{2+}-\mathrm{Mg}^{2+}$-free $\mathrm{HBSS}$ at $37^{\circ} \mathrm{C}$ for 15 min; they were then dissociated by trituration with a glass Pasteur pipette and plated at a density of 4 or $5 \times 10^{5} / \mathrm{cm}^{2}$ in 35 $\mathrm{mm}$ culture dishes with glass coverslips. The glass coverslips in each dish was pretreated with poly-D-lysine (Sigma) for $2 \mathrm{hr}$ ( $500 \mu \mathrm{g} / \mathrm{ml}$ in borate buffer), washed three times, and air-dried before cell plating. The plating medium consisted of Dulbecco's modified Eagle's medium(Invitrogen, San Diego, CA), $500 \mu \mathrm{M}$ Glutamax (Invitrogen), 10\% fetal bovine serum and 10\% horse serum (Hyclone, Logan, UT). On the second day after plating, the culture medium was replaced by DMEM containing 500 $\mu \mathrm{M}$ Glutamax (Invitrogen) and 5\% horse serum. Cells were maintained in a $\mathrm{CO}_{2}$ incubator at $37^{\circ} \mathrm{C}$, and the culture medium was replaced with DMEM containing $500 \mu \mathrm{M}$ Glutamax and 5\% horse serum every $3 \mathrm{~d}$.

\section{Electrophysiological recordings}

Whole-cell current-clamp and voltage-clamp recordings were obtained from pyramidal-type cells after 10-14 days in vitro with standard techniques [15]. The external bath solution contained $145 \mathrm{mM} \mathrm{NaCl}, 5 \mathrm{mM} \mathrm{KCl}, 2 \mathrm{mM} \mathrm{CaCl}_{2}, 1 \mathrm{mM} \mathrm{MgCl}$,
$10 \mathrm{mM}$ glucose, and 10mM HEPES, $\mathrm{pH}$ 7.2. The pipette solution contained $145 \mathrm{mM} \mathrm{KCl}, 0.1 \mathrm{mM} \mathrm{CaCl}, 11 \mathrm{mM}$ EGTA, $1 \mathrm{mM}$ $\mathrm{MgCl}_{2}, 10 \mathrm{mM}$ HEPES, and 2mM ATP, $\mathrm{pH}$ 7.2. Signals were recorded with an EPC-9 patch-clamp amplifier (HEKA, Lambrecht, Germany) by using patch pipettes (resistance 4-5 $\mathrm{M} \Omega$ ) filled with the pipette solution. For voltage-clamp experiments, cells were held at membrane potential of $-60 \mathrm{mV}$. The series resistance was 8-15 M 2 . All experiments were performed at room temperature.

\section{Intracellular calcium measurement}

Intracellular calcium $\left(\left[\mathrm{Ca}^{2+}\right]_{\mathrm{i}}\right)$ levels of single neuron were measured by using fura- $2 \mathrm{AM}$ and ratiometric imaging techniques [16]. Cells were loaded for $40 \mathrm{~min}$ at $37^{\circ} \mathrm{C}$ with Fura2AM ( $2 \mu \mathrm{M}$, Molecular Probes, Eugene, OR) dissolved in dimethyl sulfoxide/10\% pluronic F-127 (Molecular Probes), rinsed, and incubated in fresh culture medium for $10 \mathrm{~min}$ before the measurement. During $\left[\mathrm{Ca}^{2+}\right]_{\mathrm{i}}$ measurement, cells were kept in modified Hanks' buffer. The fluorescence setup was as follows: the fluorescence microscopy is built around an Axiovert 100 (Zeiss, Germany); excitation light $345 \mathrm{~nm} / 380 \mathrm{~nm}$ is provided by a monochromatic system( TILL Photonics, Germany).The fluorescence signals are collected by a photomultiplier and converted to voltage values, then digitized and sent to the computer. X-chart (HEKA, Germany) is used to record the signal. Intracellular free $\mathrm{Ca}^{2+}$ concentration was measured according to the following equation: $\left[\mathrm{Ca}^{2+}\right]_{\mathrm{i}}=\mathrm{K}_{\text {eff }}\left(\mathrm{R}-\mathrm{R}_{\min }\right) /\left(\mathrm{R}_{\max }-\mathrm{R}\right) . \mathrm{K}_{\text {eff }}$ is effective binding constant. $\mathrm{R}$ is a ratio of fluorescence at two wavelengths (at excitation wavelengths of 340 and $380 \mathrm{~nm}$ ). $\mathrm{R}_{\min }$ is the limiting value that the ratio can have at zero $\left[\mathrm{Ca}^{2+}\right]_{i}$. $\mathrm{R}_{\max }^{\min }$ is the limiting value that the ratio can have at saturating $\left[\mathrm{Ca}^{2+}\right]_{\mathrm{i}}(10 \mathrm{mM})$. In our experiment, $\mathrm{R}_{\text {min }}$ was $0.1, \mathrm{R}_{\max }$ was 3.6 , and $\mathrm{K}_{\text {eff }}=1918 \mathrm{nM}$, as determined by standard calibrations.

BDNF was extracellularly applied by puffer pipettes. The puffer pipette tip ( 5 um in diameter) was set 30 um away from the cell.

\section{Drugs}

Brain-Derived Neurotrophic Factor (BDNF) was purchased from Sigma. K-252a and U-73122 were obtained from Calbiochem. All other chemicals were from Sigma. The duration for BDNF application was 30s. U-73122 $(5 \mu \mathrm{M})$ was added $30 \mathrm{~min}$ prior to the application of BDNF. K252a (200 nm) was added 20 min prior to the intracellular calcium measurement.

\section{Results}

BDNF increases spontaneous activity in dissociated cultures of cortical neurons

To investigate the role of BDNF in regulating the overall excitability of dissociated cultures of cortical neurons, spontaneous action potentials in neurons with pyramidal morphology were recorded using whole-cell current-clamp configuration. Bath application of BDNF at $100 \mathrm{ng} / \mathrm{ml}$ increased the average spontaneous action

He/Gong/Luo 


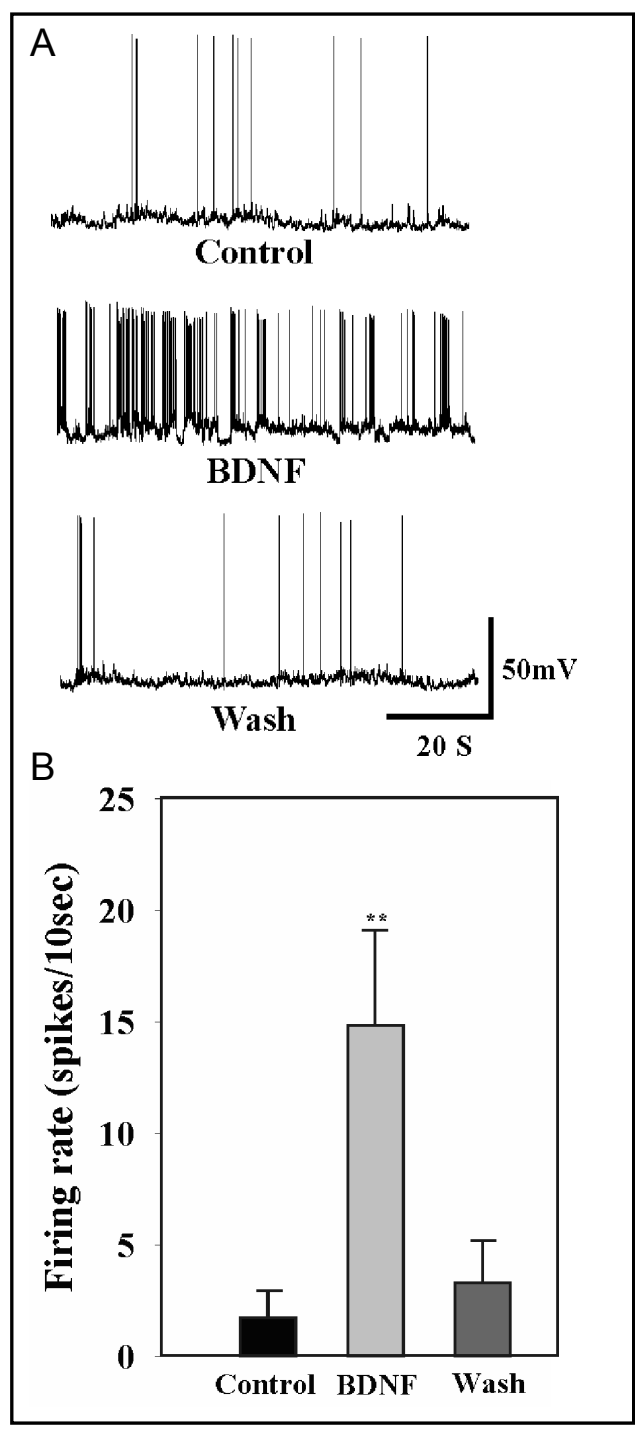

Fig. 1. Potentiation of neuronal activity by BDNF. (A) Voltage traces recorded from a cortical neuron under a current-clamped mode. Treatment of BDNF(100 ng/ml) markedly increased the spike frequency. Top trace: a representative voltage trace before the application of BDNF was shown; middle trace: a voltage trace after the bath application of BDNF was shown; bottom trace: a recorded voltage trace after washout of BDNF for $6 \mathrm{~min}$ was shown. (B), Mean group data for the effect of BDNF on firing rate $\left(\mathrm{n}=10\right.$ cells; $\left.{ }^{*} \mathrm{p}<0.01\right)$.

potential firing rates of neurons within $3 \sim 5 \mathrm{~min}$ of application (Fig. 1A). This effect appeared 3-5 min after the addition of BDNF and gradually recover to baseline levels within 3-8 min after BDNF washout .On average, firing rates increased $>8$-fold during $\mathrm{BDNF}$ exposure (Fig. 1B)[the mean control firing rate $=1.75 \pm 1.2$ spikes

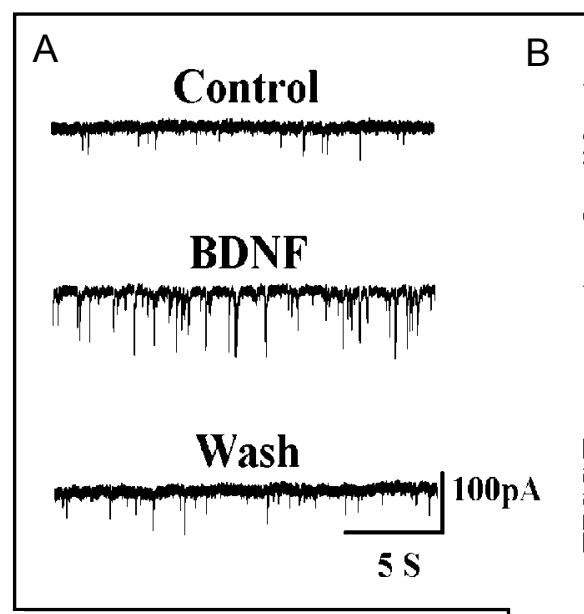

Fig. 2. Potentiation of synaptic transmission by BDNF. (A) Shown is an example of recordings. The effect of BDNF (100 ng/ $\mathrm{ml}$ ) on the EPSCs appeared 3 min after application. The increased frequency and the increased magnitude recovered to baseline $\sim 5$ min after washout of BDNF. (B) Mean group data for the effect of BDNF on EPSCs frequency $(\mathrm{n}=9$ cells; $* * \mathrm{p}<0.01)$. (C) Mean group data for the effect of BDNF on EPSCs magnitude ( $\mathrm{n}=9$ cells; $\mathrm{p}<0.01$ ).

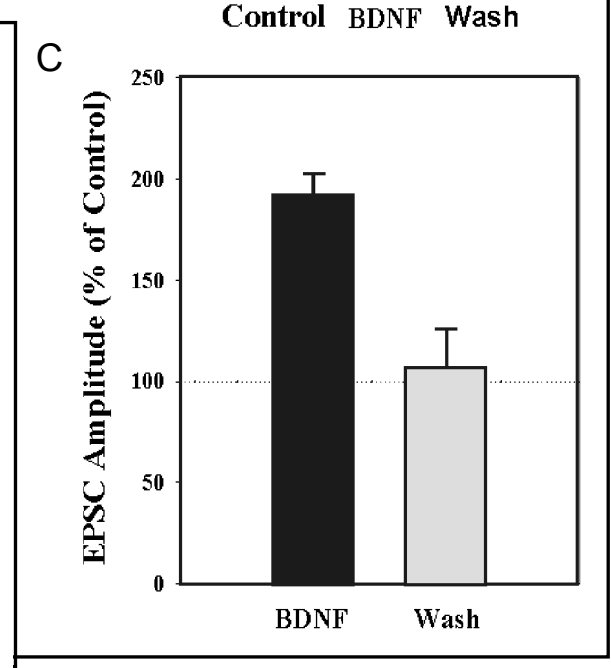

per $10 \mathrm{sec}$; the mean firing rate during BDNF application $=14.82 \pm 4.2($ mean $\pm S D ; n=10 ; p<0.01)]$. This is consistent with the finding of Levine [8].

\section{$B D N F$ increases the frequency and the amplitude of EPSCs}

The cortical cultures contain networks of interacting neurons. Whole-cell recordings $\left(\mathrm{V}_{\mathrm{h}}=-60 \mathrm{mV}\right)$ in one cell of the network revealed spontaneous synaptic activity in the vast majority of neurons after 1 weeks in culture (Fig.2A). These currents represent action potentialdependent spontaneous EPSCs mediated by non-NMDA receptors, because they were abolished by $20 \mu \mathrm{M} \mathrm{CNQX}$, a non-NMDA receptor antagonist (data not shown). Bath application of BDNF at $100 \mathrm{ng} / \mathrm{ml}$ increased the frequency of the spontaneous EPSCs. This effect appeared 3-5 min after the addition of BDNF; gradual recovery to baseline levels occurred within 3-8 min after BDNF washout (Fig. 2A). On average, the rates of spontaneous EPSCs increased to $317 \pm 5 \%$ of control levels [the mean control EPSCs rate $=10.25 \pm 2.7$ number 
Fig. 3. BDNF induced an increase in intracellular $\mathrm{Ca}^{2+}$. (A) A cortical neuron responded to BDNF with an increase in $\left[\mathrm{Ca}^{2+}\right]_{i}$. (a) active neuron which have spontaneous $\mathrm{Ca}^{2+}$ spikes (b)silence cortical neuron. (c) continuous application of BDNF is necessary for the maintenance of a sustained elevation of intracellular $\mathrm{Ca}^{2+}$. (B) Under the existences of K252a, BDNF (100 $\mathrm{ng} / \mathrm{ml}$ ) failed to induce $\mathrm{Ca}^{2+}$ transients. The arrow in each panel indicates the beginning of BDNF application. The bar in each panel indicates the period of BDNF application.

Fig. 4. (A) In calcium-free perfusion medium a substantial calcium signal remained (b), which disappeared after loading of cortical neurons with U-73122(c). (B) Under the existences of $\mathrm{Cd}^{2+}$, BDNF still induced $\mathrm{Ca}^{2+}$ increase. However, BDNF-induced $\mathrm{Ca}^{2+}$ transients were partially blocked by $\mathrm{Cd}^{2+}(\mathrm{b})$. The arrow in each panel indicates the beginning of BDNF application. The bar in each panel indicates the period of blockers application.

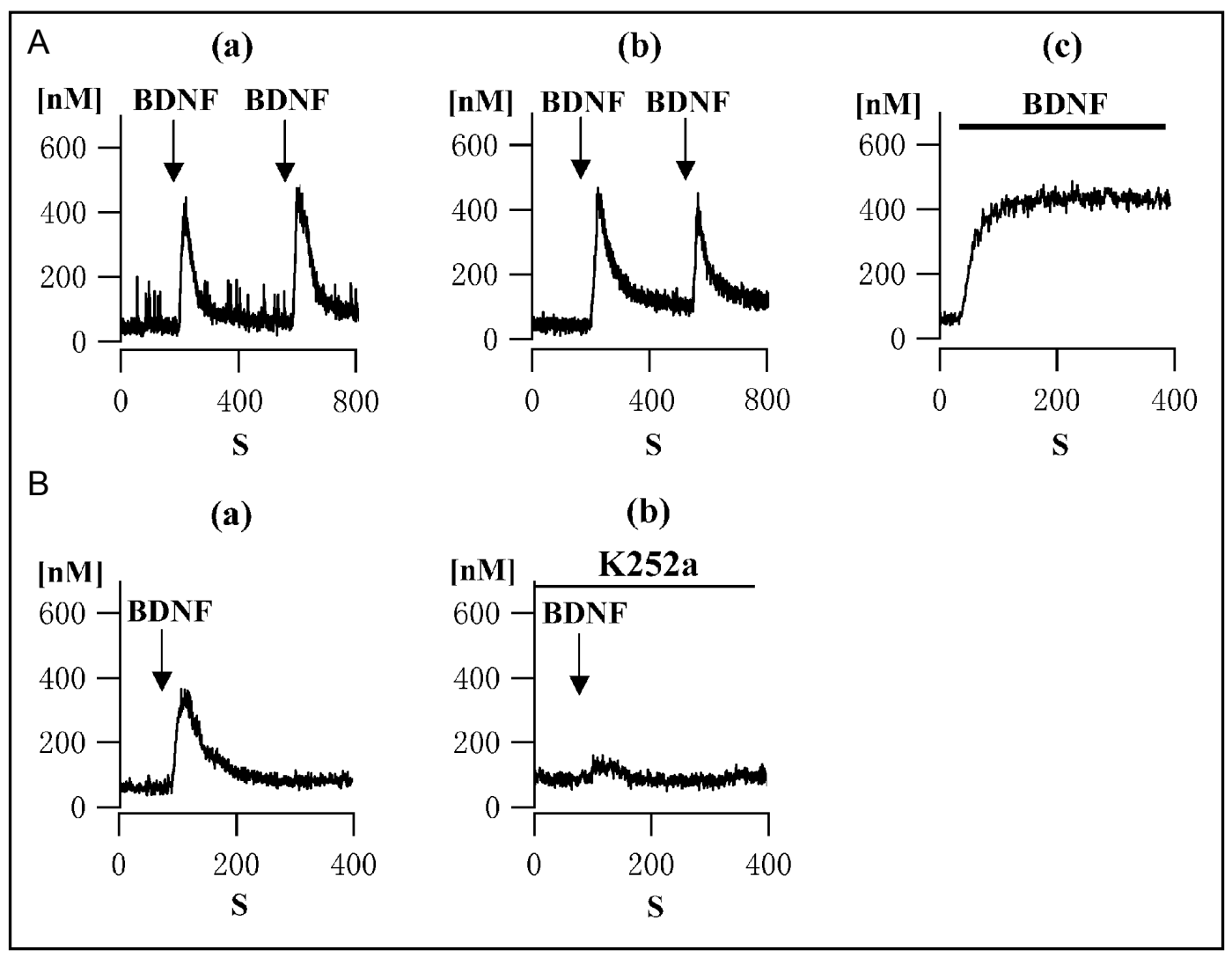

(b)

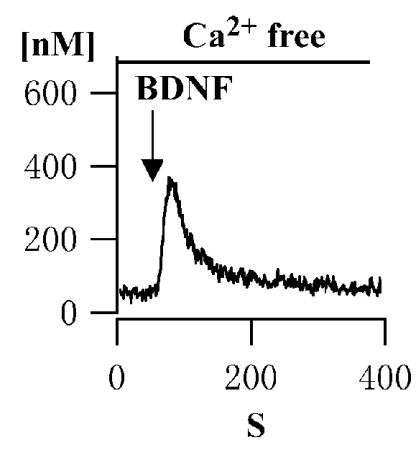

B

(a)
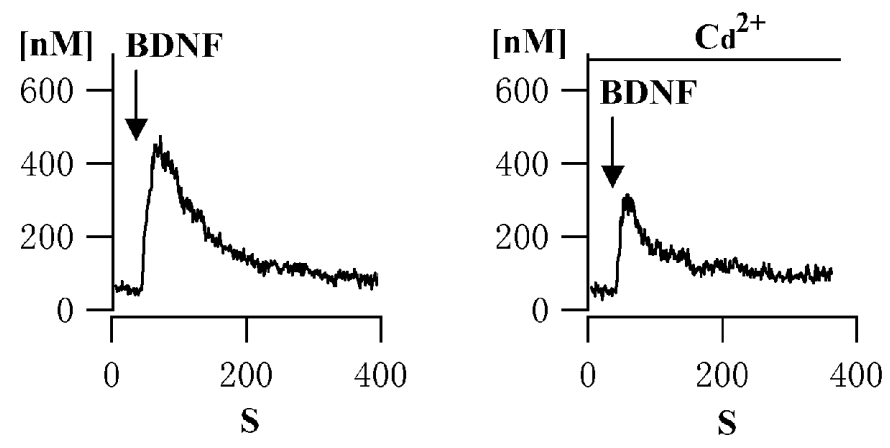

(c)

[nM] $\mathrm{Ca}^{2+}$ free+U73122

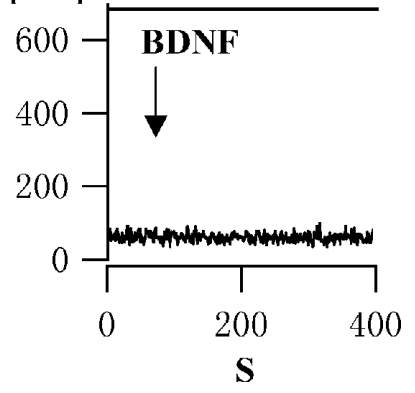


Fig. 5. (A) TTX had no effect on BDNFinduced $\mathrm{Ca}^{2+}$ transients. (B) BDNFevoked $\mathrm{Ca}^{2+}$ signals were insensitive to a cocktail of glutamate receptor blockers CNQX and APV. (C) BDNF rapidly evoked membrane subthreshold depolarization (a) and almost synchronously induced a transient calcium signal (b) in cortical neurons. The arrow in each panel indicates the beginning of BDNF application. The bar in each panel indicates the period of BDNF application.

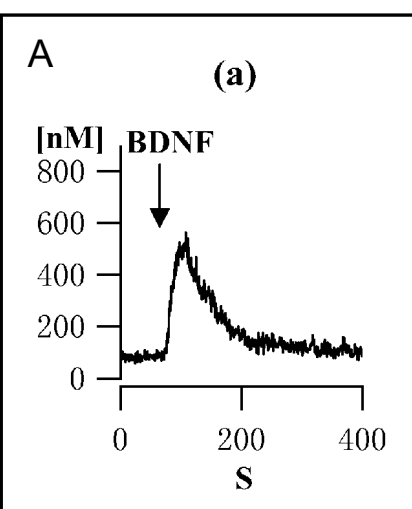

(b)

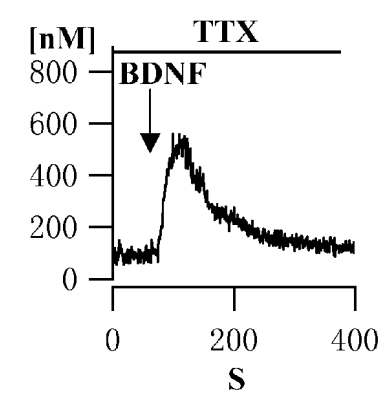

B

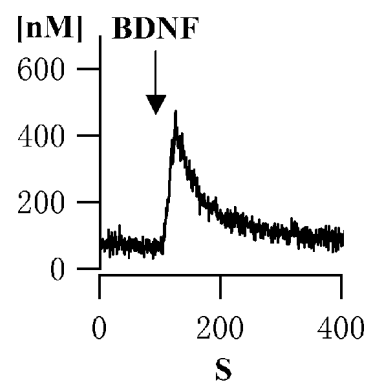

(b)

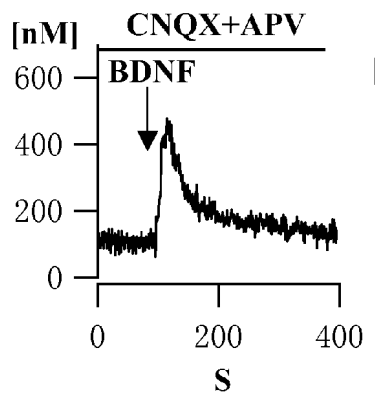

C

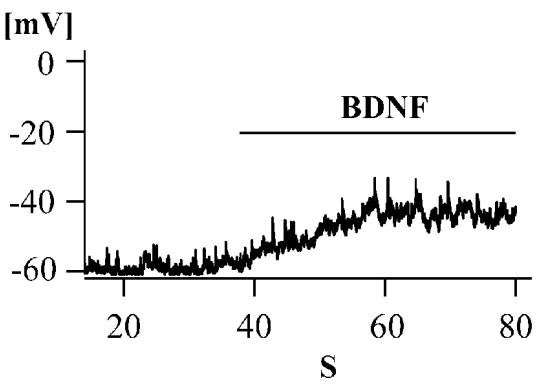

(b)

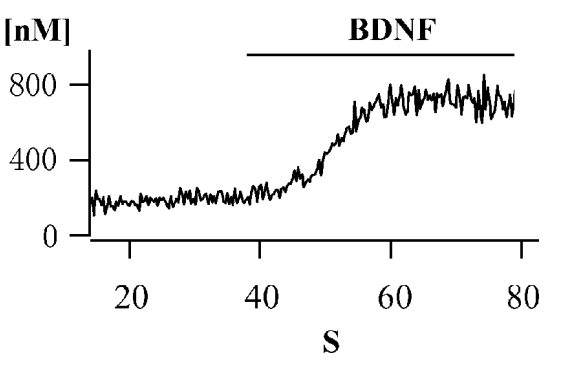

per $10 \mathrm{sec}$; the mean EPSCs rate during BDNF application $=31.59 \pm 6.5($ mean $\pm S D ; n=9 ; p<0.01)]$ (Fig. 2B). In addition, the amplitudes of the spontaneous EPSCs were increased to $192 \pm 10 \%$ of control levels by BDNF application (Fig. 2C).

$B D N F$ results both in influx of extracellular calcium and calcium mobilization from intracellular stores

This experiment was designed to characterize BDNF-induced calcium signaling in single cortical neurons in culture. After $30 \mathrm{sec}$ of BDNF application $(100 \mathrm{ng} / \mathrm{ml})$ the neurons showed a rapid rise in the concentration of $\left[\mathrm{Ca}^{2+}\right]_{\mathrm{i}}$, both in dendritic processes and cell bodies of cortical neurons ( $n=10$, Fig.3A); this elevation was reversed with the washout of BDNF and could be elicited repetitively (Fig. 3A) and continuous application of BDNF is necessary for the maintenance of a sustained elevation of intracellular $\mathrm{Ca}^{2+}$ (Fig. 3A(c)). At the same time, we found BDNF can elicit calcium transients both in silence cortical neuron and active neuron which have spontaneous $\mathrm{Ca}^{2+}$ spikes (Fig. 3A(a),(b)) . In the presence of $200 \mathrm{nM}$ K252a, a membrane-permeable inhibitor of Trk receptor tyrosine kinase, BDNF $(100 \mathrm{ng} / \mathrm{ml})$ failed to elevate intracellular $\mathrm{Ca}^{2+}$ concentration in cortex neurons $(n=6$; Fig 3B). Thus, a K252a sensitive pathway mediates the induction of the intracellular $\mathrm{Ca}^{2+}$ elevation, probably involving the Trk B receptor tyrosine kinase activity.

In calcium-free perfusion medium $(0 \mathrm{mM}$ calcium, 5 mM EGTA) a substantial calcium signal remained $\left(\mathrm{Ca}^{2+}\right.$ transients were reduced by $58 \% \pm 8 \%, n=6$, Fig. $4 A(b)$ ), which disappeared after loading of cortical neurons with $5 \mu \mathrm{M}$ U-73122 (a membrane-permeable specific PLC- $\gamma$ inhibitor) (Fig. 4A(c)), indicating that the signal partially was caused by calcium mobilization from intracellular stores through the PLC- $\gamma /$ IP3 pathway. Under the existences of $\mathrm{Cd}^{2+}$ (voltage-dependent $\mathrm{Ca}^{2+}$ channel blocker, $100 \mu \mathrm{M})$, BDNF still induced $\mathrm{Ca}^{2+}$ increase $\left(\mathrm{Cd}^{2+}\right.$ reduced the calcium transients by $38 \% \pm 10 \%, n=6$, Fig. 4B). BDNF-evoked $\mathrm{Ca}^{2+}$ signals were altered neither by tetrodotoxin $(404 \pm 102 \mathrm{nM}$ without TTX and $402 \pm 99 \mathrm{nM}$ with TTX; $n=5$ ), nor by a cocktail of glutamate receptor blockers CNQX and APV $(393 \pm 84 \mathrm{nM}$ without CNQX/ APV and 391 $\pm 83 \mathrm{nM}$ with CNQX/APV; n=5 ) (Fig. 5A.B). We also found BDNF could rapidly evoke membrane subthreshold depolarization and almost synchronously induce a transient calcium signal in cortical neurons (Fig. 5C). All the above results indicate BDNFevoked $\mathrm{Ca}^{2+}$ signals depend on calcium mobilization from intracellular stores and the influx of extracellular calcium may be mainly controlled by voltage-dependent $\mathrm{Ca}^{2+}$ channels. 


\section{Discussion}

Neurotrophins play a fundamental role in the survival and differentiation of many types of neurons. In addition to developmental regulation, neurotrophins are also important factors in synaptic plasticity and memory formation. Moreover, BDNF is essential to synaptic transmissions, activity-dependent synaptic plasticity and long-term memory $[4,5]$. Besides potentiate excitatory synaptic transmission [7, 8], application of BDNF to neurons also can activate a TRPC3-dependent cation current [17], cause membrane depolarization within a few milliseconds through TrkB activity-dependent activation of a novel form of membrane sodium channels [18], and induce $\mathrm{Ca}^{2+}$ mobilization [19-21]. Many studies subsequent to that of Lohof et al [6] have shown that BDNF and other neurotrophins can modulate synaptic transmission in cultured neurons [22-24], hippocampal slices [25-27], visual cortex slices [11,28], and hippocampal neurons in vivo [12]. However, in these studies, there are some inconsistency and varied results in the reported acute effects on apparently similar systems, which may be due to differences in the preparations and experimental procedures. Levine et al [8] reported that BDNF enhanced excitatory synaptic transmission in cultured hippocampal neurons. In rat hippocampal slices, Tanaka et al [29] described the inhibition of GABA $A_{A}$ synaptic responses by BDNF. Frerking et al also reported BDNF modulated inhibitory, but not excitatory, transmission in the CA1 region of the hippocampus [27]. BDNF acutely inhibited AMPAmediated currents in developing sensory relay neurons was reported by Balkowiec et al [30]. As far as BDNFinduced $\mathrm{Ca}^{2+}$ mobilization, there are also some varied results have been reported. Li et al [9] reported BDNF induced intracellular $\mathrm{Ca}^{2+}$ elevation depended on extracellular $\mathrm{Ca}^{2+}$ in hippocampal neurons. Numakawa et al [21] reported BDNF-induced $\mathrm{Ca}^{2+}$ elevation was mediated by IP3 receptor rather than by an influx of extracellular $\mathrm{Ca}^{2+}$. Mizoguchi et al [20] found a brief BDNF could cause sustained intracellular $\mathrm{Ca}^{2+}$ elevation in rat visual cortex neurons, which was dependent on intracellular $\mathrm{Ca}^{2+}$ stores.

In present study we investigated the effects of BDNF on synaptic transmission and calcium signaling of cortical neuron. We found that BDNF rapidly induced potentiation of spontaneous neuron activity of cortical network. Within minutes of BDNF application to cultured cortical neurons, spontaneous firing rate was dramatically increased as was the frequency and amplitude of excitatory spontaneous postsynaptic currents (EPSCs), which is consistent with previous reports $[8,28]$. In agreement with earlier observations [19-21], we found that BDNF could also rapidly induce an increase in the intracellular $\mathrm{Ca}^{2+}$ concentration in cultured cortical neurons. In calcium-free perfusion medium, a substantial calcium signal remained, which disappeared after loading of cortical neurons with $5 \mu \mathrm{M} \mathrm{U}-73122$, it suggested that the signal partially was caused by calcium mobilization from intracellular stores through the PLC- $\gamma /$ IP3 pathway. In addition, $\mathrm{BDNF}$-induce $\mathrm{Ca}^{2+}$ transients were partially blocked by $\mathrm{Cd}^{2+}$. All data indicate that BDNF-evoked $\mathrm{Ca}^{2+}$ signals result from the influx of extracellular calcium might mainly through voltage-sensitive $\mathrm{Ca}^{2+}$ channels and the calcium mobilization from intracellular stores.

In neurons of CNS, the binding of BDNF to TrkB can activate the non-selective cation channel TRPC3 through PLC- $\gamma /$ IP3 pathway [17]. Kafitz et al reported another, much faster and distinctly different excitatory action of neurotrophins. In various types of CNS neurons, the study found that low nanomolar levels of BDNF evoke neuronal excitation by activating a Na current $\left(\mathrm{I}_{\mathrm{Na}}\right)$. This BDNF-evoked $\mathrm{I}_{\mathrm{Na}}$ underlying neuronal depolarization was activated within milliseconds and, as a function of the BDNF dose and the time of application, resulted in trains of action potentials [18]. One report identified dendritic spines as highly sensitive sites for the BDNF-evoked excitation, and demonstrated that in hippocampal dentate granule cells induction of BDNF-mediated LTP occured post-synaptically [31]. Recently, one report demonstrates that the ligand BDNF, bound to the receptor tyrosine kinase TrkB, can evoke membrane depolarization through rapid activation of the sodium channel NaV1.9 [32]. In our experiments, we found BDNF could rapidly evoke membrane subthreshold depolarization and almost synchronously induce a transient calcium signal in cortical neurons. We also found that BDNF-evoked $\mathrm{Ca}^{2+}$ signals in cortical neuron were altered by neither tetrodotoxin, nor by a cocktail of glutamate receptor blockers CNQX and APV. Therefore, it suggests that both of BDNFevoked membrane depolarization and calcium mobilization from intracellular stores through PLC- $\gamma / \mathrm{IP} 3$ pathway may be responsible for BDNF-evoked $\mathrm{Ca}^{2+}$ signals. The mechanisms of BDNF-evoked membrane depolarization in cultured cortical neurons will be investigated in our future experiments.

Previous studies have investigated whether BDNFinduced synaptic potentiation occurs pre- or post- 
synaptically. Some studies indicated that the BDNF modification of synaptic transmission occured presynaptically $[6,7,9,33]$. On the other hand, some studies indicated postsynaptic actions of BDNF. Levine et al. demonstrated BDNF modulated hippocampal synaptic transmission by increasing NMDA receptor activity [23]. BDNF, within 5 min of exposure, elicited a dose-dependent increase in phosphorylation of the Nmethyl-Daspartate receptor subunit [34, 35]. Recently, $\mathrm{Wu}$ et al. reported Brain-derived neurotrophic factor acutely enhanced tyrosine phosphorylation of the AMPA receptor subunit GluR1 via NMDA receptor-dependent mechanisms [36]. In our experiment, we found some interesting thing about the onset/time scale of the BDNF effect: a 30 second BDNF application could induce a transient calcium signal, while it took 3 to 5 minutes for BDNF to induce synaptic potentiation. We also found the time needed for BDNF-induced synaptic potentiation was consistent with the time for BDNF to enhance the phosphorylation of NMDA receptor subunit 1 and AMPA receptor subunit GluR1 [34-36]. In addition, Kovalchuk et al. demonstrated BDNF pulses failed to induce any transient calcium signals when applied to the axon [31]. Thus, enhancement of the NMDA and the AMPA receptor activity through phosphorylation by BDNF was a better explanation for BDNF-induced potentiation of the frequency and the amplitude of EPSCs than the presumption that BDNF-induced transient calcium signals increased the release of presynaptic vesicles. Namely, our results support the postsynaptic mechanism. However, BDNF-induced transient calcium signals may play an important role in signal cascades of the phosphorylation of NMDA receptor and AMPA receptor by BDNF. Future experiments that block BDNF signal pathway selectively in pre- or postsynaptic neurons will address this question directly.

\section{Acknowledgements}

This work was supported by Joint Research Fund for Overseas Chinese Young Scholars (Grant No. 30328014), National Natural Science Foundation of China (30170306), and National Natural Sciences Foundation of China (30370463).

\section{References}

\footnotetext{
1 Barbacid M: The Trk family of $>8$ neurotrophin receptors. J Neurobiol 1994;25:1386-1403.

-2 Kaplan DR, Miller FD: Neurotrophin signal transduction in the nervous system. Curr Opin Neurobiol 2000;10:381-391.

- Huang EJ, Reichardt LF: Neurotrophins: roles in neuronal development and $>9$ function. Annu Rev Neurosci 2001;24:677-736.

4 McAllister AK, Katz LC, Lo DC: Neurotrophins and synaptic plasticity. Annu Rev Neurosci 1999;22:295-318.

$\rightarrow 5$ Poo MM: Neurotrophins as synaptic $>10$ modulators. Nat Rev Neurosci 2001;2:24-32.

6 Lohof AM, Ip NY, Poo MM: Potentiation of developing neuromuscular synapses by the neurotrophins $>_{11}$ NT-3 and BDNF. Nature 1993;363:350353.

7 Lessmann V, Gottmann K, Heumann R: BDNF and NT-4/5 enhance glutamatergic synaptic transmission in cultured hippocampal neurons. NeuroReport 1994;6:21-25.
}

Levine ES, Dreyfus CF, Black IB, Plummer MR: Brain-derived neurotrophic factor rapidly enhances synaptic transmission in hippocampal neurons via postsynaptic tyrosine kinase receptors. Proc Natl Acad Sci USA 1995;92:80748077.

Li YX, Zhang Y, Lester HA, Schuman EM, Davidson N: Enhancement of neurotransmitter release induced by brain-derived neurotrophic factor in cultured hippocampal neurons. J Neurosci 1998;18:10231-10240.

Kang H, Schuman EM: Long-lasting neurotrophin-induced enhancement of synaptic transmission in the adult hippocampus. Science 1995;267:16581662.

Akaneya Y, Tsumoto T, Kinoshita S, Hatanaka H: Brain-derived neurotrophic factor enhances long-term potentiation in rat visual cortex. J Neurosci 1997; 17:6707-6716.
Messaoudi E, Bardsen K, Srebro B, Bramham CR: Acute intrahippocampal infusion of BDNF induces lasting potentiation of synaptic transmission in the rat dentate gyrus. J Neurophysiol 1998;79:496-499.

Purcell AL, Carew TJ: Tyrosine kinases, synaptic plasticity and memory: insights from vertebrates and invertebrates. Trends Neurosci 2003;26:625-630.

Banker GA, Cowan WM: Rat hippocampal neurons in dispersed cell culture. Brain Res 1977;126:379-425.

Hamill OP, Marty A, Neher E, Sakmann B, Sigworth FJ: Improved patch-clamp techniques for high-resolution current recording from cells and cell-free membrane patch. Pflügers Arch 1981;391:85-100.

Grynkiewicz G, Poenie M, Tsien RY: A new generation of $\mathrm{Ca}^{2+}$ indicators with greatly improved fluorescence properties. J Biol Chem 1985;260:34403450 . 
17 Li HS, Xu XZ, Montell C: Activation of a TRPC3-dependent cation current through the neurotrophin BDNF. Neuron 1999;24:261-273.

18 Kafitz KW, Rose CR, Thoenen H, Konnerth A: Neurotrophin-evoked rapid excitation through TrkB receptors. Nature 1999;401:918-921.

$>19$ Berninger B, Garcia DE, Inagaki N, >25 Hahnel C, Lindholm D: BDNF and NT-3 induced intracellular $\mathrm{Ca}^{2+}$ elevation in hippocampal neurons. NeuroReport 1993;4:1303-1306.

$>20$ Mizoguchi Y, Nabekura J: Sustained intracellular $\mathrm{Ca}^{2+}$ elevation induced by a brief BDNF application in rat visual cortex neurons. NeuroReport 2003;14:1481-1483.

21 Numakawa T, Yamagishi S, Adachi N, Matsumoto T, Yokomaku D, Yamada M, Hatanaka H: Brain-derived neurotrophic factor-induced potentiation of $\mathrm{Ca}^{2+}$ oscillations in developing cortical neurons. J Biol Chem 2002;277:65206529.

$>22$ Kim HG, Wang T, Olafsson P, Lu B: Neurotrophin 3 potentiates neuronal activity and inhibits $\gamma$-aminobutyratergic synaptic transmission in cortical neurons. Proc Natl Acad Sci USA 1994;91:1234112345.

23 Levine ES, Crozier RA, Black IB, Plummer MR: Brain-derived neurotrophic factor modulates hippocampal synaptic transmission by increasing $\mathrm{N}$ methyl-D-aspartic acid receptor activity. Proc Natl Acad Sci USA 1998;95:1023510239.
24 Li YX, Xu Y, Ju D, Lester HA, Davidson N, Schuman EM: Expression of a dominant negative TrkB receptor, T1, reveals a requirement for presynaptic signaling in BDNF-induced synaptic potentiation in cultured hippocampal neurons. Proc Natl Acad Sci USA 1998;95:10884-10889.

Kang H, Schuman EM: A requirement for local protein synthesis in neurotrophininduced hippocampal synaptic plasticity. Science 1996;273:1402-1406.

-26 Gottschalk W, Pozzo-Miller LD, Figurov A, Lu B: Presynaptic modulation of $>34$ synaptic transmission and plasticity by brain-derived neurotrophic factor in the developing hippocampus. J Neurosci 1998;18:6830-6839.

Frerking M., Malenka RC, Nicoll RA: Brain-derived neurotrophic factor BDNF modulates inhibitory, but not excitatory, transmission in the CA 1 region of the hippocampus. J Neurophysiol 1998;80:3383-3386.

28 Carmignoto G, Pizzorusso T, Tia S, Vicini $\mathrm{S}$ : Brain-derived neurotrophic factor and nerve growth factor potentiate excitatory synaptic transmission in the rat visual cortex. J Physiol 1997;498:153164.

29 Tanaka T, Saito H, Matsuki N: Inhibition of GABAA synaptic responses by brainderived neurotrophic factor (BDNF) in rat hippocampus. J Neurosci 1997;17:2959-2966.

30 Balkowiec A, Kunze DL, Katz DM: Brain-derived neurotrophic factor acutely inhibits AMPA-mediated currents in developing sensory relay neurons. J Neurosci 2000;20:1904-1911.
Kovalchuk Y, Hanse E, Kafitz KW, Konnerth A: Postsynaptic induction of BDNF-mediated long-term potentiation. Science 2002;295:1729-1734.

Blum R, Kafitz KW, Konnerth A: Neurotrophin-evoked depolarization requires the sodium channel NaV1.9. Nature 2002;419:687-693.

Jovanovic JN, Czernik AJ, Fienberg AA, Greengard P, Sihra TS: Synapsins as mediators of BDNF-enhanced neurotransmitter release. Nat Neurosci 2000;3:323-329.

Suen PC, Wu K, Levine ES, Mount HTJ, $\mathrm{Xu}$ JL, Lin SY, Black IB: Brain-derived neurotrophic factor rapidly enhances phosphorylation of the postsynaptic Nmethyl-D-aspartate receptor subunit 1 . Proc Natl Acad Sci USA 1997;94:81918195.

35 Lin SY, Wu K, Levine ES, Mount HTJ, Suen PC, Black IB: BDNF acutely increases tyrosine phosphorylation of the NMDA receptor subunit 2B in cortical and hippocampal postsynaptic densities. Mol Brain Res 1998;55:20-27.

Wu K, Len GW, McAuliffe G, Ma C, Tai JP, Xu F, Black IB: Brain-derived neurotrophic factor acutely enhances tyrosine phosphorylation of the AMPA receptor subunit GluR1 via NMDA receptor-dependent mechanisms. Mol Brain Res 2004;130:178-186 